\title{
Sensitivity of Staphylococcus aureus Isolated from Nasal and Throat of Pre-Clerkship Students to Antibiotics
}

\author{
Suci Rahayu ${ }^{1 *}$, Dian Widiyanti ${ }^{1}$, M Arsyad $^{1}$ \\ $1^{*}$ Faculty of Medicine, YARSI University. Universitas Yarsi Kav. 13, Jalan Letjen Suprapto, Kota Jakarta Pusat, Daerah \\ Khusus Ibukota Jakarta, Indonesia 10510
}

DATA OF ARTICLE:

Received: 25 Feb 2020

Reviewed: 20 Apr 2020

Revised: 11 May 2020

Accepted: 30 Jun 2020

*CORRESPONDENCE:

suciayuu@yahoo.com

DOI:

$10.18196 / \mathrm{mm} .200251$

TYPE OF ARTICLE:

Research

\begin{abstract}
Clerkship students potentially transmit CA-MRSA bacteria to patients, so it is necessary to do early detection and appropriate treatment to prevent transmission. The research objective was to determine the sensitivity pattern of Staphyllococcus aureus nasal and throat swabs isolated from students to antibiotics. This research is descriptive-analytic with nasal and throat swab samples of healthy students. Each sample was obtained 60 nose and 60 throat swabs. The identification of S. aureus was carried out by macroscopic, gram staining, catalase test, and MSA test. Sensitivity pattern test using the Kirby-Bauer method. Statistical analysis using the Mann-Whitney. The result shows that S. aureus isolated from nasal swabs was $23.3 \%$ and throat by $10 \%$. The positive prevalence of MRSA carriers was $1.7 \%$. All isolates were sensitive to Methicillin, Vancomycin, Imipenem, Ofloxacin, and Ciprofloxacin, and were resistant to Penicillin. There was no difference between the number of $\mathrm{S}$. aureus isolates from nose and throat swabs ( $p>0.05)$. It was concluded that $S$. aureus was more common in nasal than in the throat isolate. The positive prevalence of MRSA carriers among students is $1.7 \%$. All isolates sensitive to Methicillin, Vancomycin, Imipenem, Ofloxacin, and Ciprofloxacin but were resistant to Penicillin.
\end{abstract}

Keywords: Sensitivity; Staphylococcus aureus; MRSA; Antibiotics.

\begin{abstract}
Abstrak: Mahasiswa koasisten berpotensi menularkan bakteri CA-MRSA kepada pasien, sehingga perlu dilakukan deteksi dini dan pengobatan secara tepat untuk mencegah penularan. Tujuan penelitian adalah mengetahui pola sensitivitas S. aureus swab nasal dan tenggorok yang diisolasi dari mahasiswa pra-koas terhadap beberapa antibiotik. Penelitian bersifat deskriptif analitik dengan sampel swab nasal dan tenggorok mahasiswa sehat. Diperoleh sampel masing-masing 60 swab hidung dan 60 swab tenggorok. Identifikasi S. aureus dilakukan secara makroskopik, pengecatan gram, uji katalase, dan uji MSA. Uji pola kepekaan menggunakan metode Kirby-bauer. Analisis statistik menggunakan uji MannWhitney. S. aureus hasil isolasi swab hidung sebesar 23,3\% dan swab tenggorok sebesar 10\%. Prevalensi positif carrier MRSA sebesar 1,7\%. Semua isolat swab hidung dan tenggorok masih sensitif terhadap Methicillin, Vancomycin, Imipenem, Ofloxacin, dan Cyprofloxacin tetapi resisten terhadap Penicillin. Tidak ada perbedaaan antara jumlah S. aureus isolat swab hidung dengan tenggorok ( $p>0.05)$. Disimpulkan bahwa S. aureus lebih banyak ditemukan pada isolat swab hidung daripada tenggorok. Prevalensi positif carrier MRSA pada mahasiswa pra-koas Universitas Yarsi sebesar 1,7\%. S. aureus isolat swab hidung dan tenggorok masih sensitif terhadap Methicillin, Vancomycin, Imipenem, Ofloxacin, dan Cyprofloxacin namun sudah resisten terhadap Penicillin
\end{abstract}

Kata Kunci: Sensitivitas; Staphylococcus aureus; MRSA; Antibiotik.

\section{INTRODUCTION}

Staphylococcus aureus is a normal flora in the nose, throat, and human skin. In the United States, 260,000 out of 2 million (13\%) cases of nosocomial infection caused by $\mathrm{S}$. aureus bacteria. Staphylococcus aureus caused by various types of skin and soft tissue infections, osteomyelitis, necrotizing pneumonia, and bacteremia. Infection 
occurs due to the colonization of S. aureus bacteria in the patient's body as the source, so that opportunistic infections can occur in the patient himself or there can be transmission in other sufferers. The infection becomes difficult to treat if the S.aureus strain that plays a role is the methicillinresistant $S$. aureus (MRSA) strain because MRSA is resistant to broad-spectrum antibiotics commonly used in hospitals. ${ }^{1}$ Methicillin-Resistant S. aureus (MRSA) is $S$. aureus that has resistance to Blactamase class antibiotics including Penicillin, Methicillin, Oxacillipenicillinn, Nafcillin, and Cephalosporin. $^{2}$

Staphylococcus aureus can potentially cause infections in bones, joints, surgical wounds, bloodstream, heart, and lungs which can be lifethreatening to sufferers. ${ }^{3}$ In 2001, the World Health Organization (WHO) launched a global strategy in dealing with expanding antibiotic resistance. MRSA bacteria were initially only resistant to $\beta$-lactam ringed antimicrobials, but in their development, there was also immunity against the quinolones, aminoglycosides, tetracyclines, and even vancomycin. Bacterial transmission is transferred from one patient to another because it is through non-sterile medical devices. Transmission can also be via air or room facilities such as blankets or bedding. ${ }^{4}$

In the United States, MRSA is resistant to 6 antimicrobial classes, and in Canada, MRSA is resistant to 3 antimicrobial of classes. The highest resistance occurred against erythromycin (95\%) and clindamycin (88\%). In these areas, in general, vancomycin can still be used effectively. Vancomycin is the drug of choice for MRSA infections such as bacteriemia, endocarditis, pneumonia, and postoperative complications. ${ }^{5}$

Currently, it is known that there are two types of MRSA, namely Hospital Acquired MRSA / HA-MRSA which is found in hospitals and health places, and Community-Acquired MRSA / CA-MRSA which is found spreading in public places such as gyms, luggage storage (lockers), school, and household furniture. Students who are carriers of CA-MRSA can transmit to patients, so it is necessary to do prevention and treatment appropriately. ${ }^{3}$

Allah SWT has equipped mankind with a very perfect immune system from birth. Excessive administration of antibiotics will damage the immune system. In Islamic medicine, antibiotics should not contain unclean objects that are haram for human consumption. ${ }^{6}$

Therefore, it is necessary to reveal the susceptibility pattern of the $S$. aureus bacteria isolated from nose and throat to detect CA-MRSA carriers, especially for pre-clerkship students who will work in the hospital. Early detection is important so that its spread can be prevented and treated as early as possible.

\section{MATERIALS AND METHOD}

This type of research is descriptive-analytic. The research design included sampling from nose and throat swabs, identification of bacteria from examination samples, counting the number of germs, processing, and analyzing data, accompanied by a questionnaire as supporting data.

The Samples takes from nasal and throat swabs from 60 final year students of the Faculty of Medicine, YARSI University. The total swab samples examined were 120. Furthermore, samples taken from nose and throat swabs were immersed or suspended in a tube containing $\mathrm{BHI}$ broth. The suspension incubated for 18-24 hours at $370 \mathrm{C}$. The species that grew on the suspension identified using the identification method according to applicable standards in the Microbiology Laboratory of the Faculty of Medicine, YARSI University. Identification of growing bacterial colonies consisted of microscopic examination with gram stain, MSA test on mannitol salt agar, macroscopic observation on blood agar plates, and catalase test. Bacterial colonies showing the characteristics of $S$. aureus bacteria that tested for antibiotic sensitivity using the Kirby-Bauer method. The data obtained were statistically tested using the Mann-Whitney test with the SPSS for Windows program.

\section{RESULT}

Examination of the number of bacteria from the nasal swab samples of respondents who were positive for $S$. aureus was obtained as many as $14(23.3 \%)$. Meanwhile, only six of the throat swabs were positive for $S$. aureus (10\%). The results showed that there were more $\mathrm{S}$. aureus isolated from nose than throat (Table 1). The results of the Mann-Whitney test showed $p>0.05$, there was no difference between the number of $S$. aureus isolated from the nose and throat swabs of YARSI University pre-clerkship students.

The majority of $\mathrm{S}$. aureus isolated from nasal swabs were still sensitive to Methicillin, Vancomycin, Imipenem, Ofloxacin, and Ciprofloxacin and resistant to Penicillin. One isolate intermediate to Vancomycin (Table 2).

S. aureus isolated from throat swabs showed that all isolates were still sensitive to Vancomycin and Imipenem. One isolate was resistant to methicillin and ofloxacin. One isolate intermediate to Methicillin and Ciprofloxacin. $33 \%$ of isolates are 
sensitive to Penicillin. The majority of $S$. aureus throat swab isolates were still sensitive to Methicillin, Vancomycin, Imipenem, Ofloxacin, and Ciprofloxacin and resistant to Penicillin (Table 3).

Table 1. Distribution of Nose and Throat Swab Staphylococcus aureus Isolates

\begin{tabular}{l|l|l}
\hline \multicolumn{1}{c|}{ Swab } & \multicolumn{1}{c|}{$\begin{array}{c}\text { Number of } \\
\text { Isolates }\end{array}$} & \multicolumn{1}{|c}{$\begin{array}{c}\text { Percentage } \\
(\%)\end{array}$} \\
\hline Nose $(\mathrm{N}=60)$ & 14 & 23.3 \\
Throat $(\mathrm{N}=60)$ & 6 & 10 \\
\hline
\end{tabular}

Table 2. Sensitivity Pattern of S. aureus Nasal Swab Isolate to Several Antibiotics

\begin{tabular}{ccccc}
\hline No & Antibiotic & \multicolumn{3}{c}{ Persentage (\%) (N=20) } \\
\cline { 3 - 5 } & & Sensitive & Intermediate & Resisten \\
\hline 1 & Methicillin & 66.7 & 16.7 & 16.7 \\
2 & Vancomycin & 100 & 0 & 0 \\
3 & Imipenem & 100 & 0 & 0 \\
4 & Penicillin & 33.3 & 0 & 66.7 \\
5 & Ofloxacin & 83.3 & 0 & 16.7 \\
6 & Ciprofloxacin & 83.3 & 16.7 & 0 \\
\hline
\end{tabular}

Table 3. Sensitivity Pattern of S. aureus Throat Swab Isolate to Several Antibiotics

\begin{tabular}{ccccc}
\hline No & Antibiotic & \multicolumn{3}{c}{ Percentage (\%) (N=20) } \\
& & Sensitive & Intermediate & Resisten \\
\hline 1 & Methicillin & 100 & 0 & 0 \\
2 & Vancomycin & 93 & 7 & 0 \\
3 & Imipenem & 100 & 0 & 0 \\
4 & Penicillin & 0 & 0 & 100 \\
5 & Ofloxacin & 100 & 0 & 0 \\
6 & Ciprofloxacin & 100 & 0 & 0 \\
\hline
\end{tabular}

\section{DISCUSSION}

This study proved that S. aureus isolates were found more frequently from nasal swabs than from throat swabs. Although from the statistical test there was no significant difference between the number of $S$. aureus bacteria, nasal and throat swab isolates among YARSI University pre-co assistent students. This study supports previous research which states that the nose or anterior nares are the main reservoirs of $S$. aureus bacteria in humans. ${ }^{7}$ Most community-acquired $S$. aureus infections are autoinfected where the strain of the patient is a congenital (carrier) found in the anterior nose or nares, skin, or both. ${ }^{8}$

Staphylococcus aureus is one of the main infectious agents in hospitals and communities, and it has been reported that around $37 \%$ of healthy people carry the $S$. aureus bacteria. ${ }^{9}$ The nasal cavity is the natural ecology of the $S$. aureus bacterial species. Carrier S. aureus in the nasal cavity is also a risk factor for nosocomial infections in hospitalized patients.

Nasal swab isolates $S$. aureus bacteria were still sensitive to methicillin, imipenem, ofloxacin, and ciprofloxacin antibiotics. There was one $S$. aureus from throat swab isolate including MRSA and one isolate resistant to ofloxacin. Almost all isolates showed resistance to penicillin antibiotics.

The sensitivity test shows that $S$. aureus isolated from nasal throat swabs are still sensitive to imipenem. These results show consistent with the research of Nurmala et al. (2015), ${ }^{6}$ imipenem showed the highest sensitivity of $78.1 \%$ for grampositive bacteria. This could explain that imipenem antibiotics can be an alternative drug for $S$. aureus therapy. Imipenem belongs to the carbapenem group which is a beta-lactam group whose chemical structure is different from penicillins and cephalosporins. This drug also has a broader antimicrobial spectrum. Imipenem is a broadspectrum antibiotic, including gram-positive and gram-negative bacteria, both aerobic and anaerobic and bactericidal. Imipenem is used for the treatment of severe infections by sensitive germs, including nosocomial infections that are resistant to other antibiotics.

One of the possible causes of the high level of S. aureus resistance to penicillin antibiotics is due to MRSA. Methicillin-resistant S. aureus (MRSA) resistance to beta-lactam class antimicrobials is due to the bacteria having a mutant protein penicillinbinding protein $2 \mathrm{a}$ (PBP2a or PBP 2) encoded by the mecA gene. The mechanism of the mecA gene to express PBP2a is that penicillin acts by binding to PBP and kills bacteria by activating its autolytic enzymes. ${ }^{12}$ PBP2a is encoded by the mecA gene in the transposon. This can also be called resistance utilizing transposons. Transposons are DNA structures that can migrate through the genome of an organism. This structure is part of the plasmid but can also originate from the bacterial chromosome. If the transposon contains a resistant gene that inserts into the plasmid it will move to 
another cell. Thus, if the plasmid can self-replicate on a new host or if the transposon moves to another plasmid capable of replicating or inserting into chromosomes, the cell becomes resistant to antibiotics.

The resistance mechanism to methicillin antibiotics in S. aureus bacteria can occur because of the presence of genes located in the Mobile Genetic Element (MGEs), such as plasmids and transposons, these resistance genes are located on the cassette of the mec chromosome. ${ }^{14}$ The possibility of transmission of MRSA carriers is not only from nosocomial origin but also from the community or what is referred to as CA-MRSA (Community-Acquired Methicillin Staphylococcus aureus), which means transmission can come from outside the health environment such as a fitness center, and can also spread by direct contact with a wound infected with MRSA (skin-to-skin contact). ) or indirectly by sharing personal equipment such as towels, razors that have been contaminated with MRSA. ${ }^{13}$

The results of the sensitivity pattern of $S$. aureus isolates from nasal and throat swab isolates to vancomycin antibiotics were three intermediate isolates. Vancomycin is the drug of choice for MRSA infection therapy. ${ }^{16}$ The decrease in vancomycin sensitivity to $S$. aureus occurs because of changes in peptidoglycan biosynthesis or the bacteria have thickened cell walls, so it is thought to be one of the factors decreasing the ability of vancomycin to diffuse into the cell walls and inhibits its synthesis. ${ }^{17}$

The emergence of Vancomycin intermediate Staphylococcus aureus (VISA) and Vancomycinresistant Staphylococcus aureus (VRSA) is very dangerous because it will make it difficult to handle multiresistant $S$. aureus in the hospital and can increase the mortality rate due to S.aureus infection. To be able to prevent VRSA, the use of vancomycin should be used in indications of severe cases such as sepsis, endocarditis, and meningitis. Therefore, research on the sensitivity pattern of $S$. aureus to Vancomycin as a Drug of Choice also needs to be carried out regularly.

The results of the sensitivity pattern on the nasal swab to penicillin antibiotics showed that all isolates were resistant, while in the throat swab two isolates were still sensitive. This proves that penicillin antibiotics are no longer effective in the treatment of S. aureus infections. Staphylococcus aureus isolated from nasal and throat swabs are still sensitive to ofloxacin. According to lbe et al. (2013), ${ }^{19}$ ofloxacin antibiotics showed a sensitivity result of $80.4 \%$, it seems that this is the best antibiotic of choice for the treatment of CA-MRSA infections associated with rural communities in Uturu. The mechanism of bacterial resistance to antibiotics occurs both genetically and nongenetically. Genetically resistance occurs through conjugation and transduction processes between the same strains, while non-genetically resistance occurs through excessive antibiotic administration, continuous or irregular low doses. ${ }^{20}$

The majority of $\mathrm{S}$. aureus isolated from nasal and throat swabs were still sensitive to Ciprofloxacin. Ciprofloxacin antibiotic is one of the antibiotics that is effective as a substitute for Penicillin. Ciprofloxin has very mild side effects and has very little resistance to germs. ${ }^{21}$ According to Pai et al. (2013), 23 the level of antibiotic resistance to Ciprofloxacin was $11.8 \%$. Ciprofloxacin is used as an alternative to MRSA infection. ${ }^{22}$ However, other studies are reporting that Ciprofloxacin is not effective against MRSA infection with a resistance rate of $99 \%$.

\section{CONCLUSION}

Staphylococcus aureus isolates nasal swabs were more common than throat swabs. There was no significant difference between the number of $S$. aureus bacteria isolates nose and throat swabs. The prevalence of MRSA carriers in the pre co-assistent students of YARSI University is $1.7 \%$. The majority of S. aureus from nasal and throat swab isolates were still sensitive to the antibiotics Methicillin, Imipenem, Ofloxacin, and Ciprofloxacin but were resistant to Penicillin.

\section{REFERENCES}

1. Santosaningsih, Zuhriyah, dan Nurani P. Staphylococcus aureus pada Komunitas Lebih Resisten terhadap Ampisilin dibandingkan Isolat Rumah Sakit. 2011. Jurnal Kedokteran Brawijaya. Agustus 2011: 26(4). Pp 204-207.

2. Dellit TH, Duchin J, Hofmann J, \& Olson EG. Guidelines for Evaluation \& Management of Community-Associated Methicillin Resistant Staphylococcus aureus Skin and Soft Tissue Infections in Outpatient Settings. 2007. http://www.kingcounty.gov/healthservices/h ealth/communicable/providers/ /media/healt $\mathrm{h} /$ publichealth/documents/communicable/MR SA guidelines.ashx

3. Sartika. Isolasi Staphylococcus aureus dari Mukosa Hidung Perokok dan Bukan Perokok pada Buruh Makassar serta Penentuan Staphylococcus aureus Resisten Methicillin. 2008. https://core.ac.uk/reader/25489370

4. Nurkusuma DD. Faktor yang Berpengaruh Terhadap Kejadian Methicillin-Resistant 
Staphylococcus aureus (MRSA) pada Kasus Infeksi Luka Pasca Bedah Rumah Sakit Dokter Kariadi Semarang. 2009. Master Thesis. School of Posgraduate University of Diponegoro, Semarang. http://eprints.undip.ac.id/28863

5. Zaraswati D. Mikrobiologi Dasar. Universitas Makassar: Hasanuddin. 2004

6. Nurmala, Virgiandhy IGN, Andriani, Liana DF. Resistensi dan Sensitivitas Bakteri terhadap Antibiotik di RSU dr. Soedarso Pontianak Tahun 2011-2013. eJKI: April 2015:3(1): 21-28

7. Lamberts SWJ. Staphyloccous Aureus Infections Lead by The Nose. (Proefschrift). Rotterdam. Dissertation Erasmus University Rotterdam. Den Haag. 2005. file:///C:/Users/acer/Downloads/050617 Heim an.pdf

8. Sherris JC, Kenneth JR, George CR. Medical Microbiology: An Introduction to Infectious Disease. 4th ed. New York: McGraw-Hill. 2004.

9. Holý O, Vlčková J, Matoušková I, \& Kolář M. The prevalence of nasal carriage of Staphylococcus aureus and methicillinresistant S. aureus (MRSA) among general medicine students of the Palacky University Olomouc. 2015. Epidemiol Mikrobiol Imunol. 2015 Jun;64(2):98-101.

10. Kluytmans JAJW, \& Wertheim HFL. Infection Nasal Carriage of Staphylococcus aureus and Prevention of Nosocomial Infections. 2005. Infection. 2005 Feb;33(1):38. doi: 10.1007/s15010-005-4012-9

11. Setiabudy R. Antimikroba. Dalam: Gunawan SG, Setiabudy R, Nafrialdi, Elysabeth, Editor. Farmakologi dan Terapi. Ed ke-5. Jakarta: Fakultas Kedokteran Universitas Indonesia. 2012.

12. Salmenlina S. Molecular epidemiology of methicillin-resistant Staphylococcus aureus in Finland. Disertation. 2002. Helsinki: The National Public Health Institute. p. 88-92

13. Sudigdoadi S, Mekanisme Timbulnya Resistensi Antibiotik pada Infeksi Bakteri: Mikrobiologi. 2015. Fakultas Kedokteran Universitas Padjadjaran. http://pustaka.unpad.ac.id/wpcontent/uploads/2015/09/mekanismetimbulnya-resistensi-antibiotik-pada-infeksibakteri.pdf

14. Prasetio M, Barliana, Melisa I. Gen mecA sebagai faktor munculnya MethicillinResistant Staphylococcus aureus (MRSA). Medika Jurnal. 2016: 14(3):55-59.

15. Kuntaman. Pemerintah Harus Batasi Penggunaan Antibiotik. 2016. FK UNAIR. http://news.unair.ac.id/2016/04/01fk-unair-rsdr-soetomo-dorong-masyarakat-indonesiasadar-resistensi-antibiotik/

16. Choo EJ, and Henry F. Treatment of Methicillin-Resistant Staphylococcus

aureus Bacteremia. Chambers Infect Chemother. 2016 Dec; 48(4): 267273. doi: 10.3947 /ic.2016.48.4.267

17. Lowy FD. Antimicrobial resistance: the example of Staphylococcus aureus. J Clin Invest. 2003 May 1; 111(9): 1265-1273. doi: $10.1172 / \mathrm{JCl} 18535$

18. Afifurrahman K, Samadin H, \& Aziz S. Pola Kepekaan Bakteri Staphylococcus aureus terhadap Antibiotik Vancomycin di RSUP Dr. Mohammad Hoesin Palembang. Majalah Kedokteran Sriwijaya, Oktober 2014: 46 (4): 266-270.

https://doi.org/10.36706/mks.v46i4.2716

19. Ibe C, Onyeagba RA, Charles SU, Onuabuchi IA, JacobsC, Nduka CJ, Nnadozie J and Osuocha KU. Prevalence and Antibiotic Susceptibility Patterns of MethicillinResistant Staphylococcus Aureus (MRSA) Isolated from Healthy Inhabitants of Uturu Rural Communities, Abia State, Nigeria. J Natl Sci Res. 2013:3(10): 85-91

20. Soeharsono. Probiotik: Basis Ilmiah Aplikasi dan Aspek Praktis. Widya Padjajaran. Bandung. 2005. Pp. 7-11.

21. Mendell GL. \& Sande MA., Antimicrobial Agents; Goodman \& Gilman The Pharmacological Basis of Theurapeutics. 1992:2, 8 th edition; Mc Graw - Hill Incorporation. Pp $1057-64$.

22. Pai V, Rao VI, \& Rao SP. Prevalence and Antimicrobial Susceptibility Patterns of Methicillin Resistant Staphylococcus aureus (MRSA) Isolates at A Tertiary Care Hospital in Mangalore, South India. Journal of Laboratory Physicians, 2013:2(2), 82-84.

23. Gupta R, Nanda S, \& Barve S. Multi drug Resistance in Methicillin-Resistant Staphylococcus aureus (MRSA) Isolates from a University Hospital of Western India. Journal of Evolution of Medical and Dental Sciences, 2013:2(9), 1353-135 